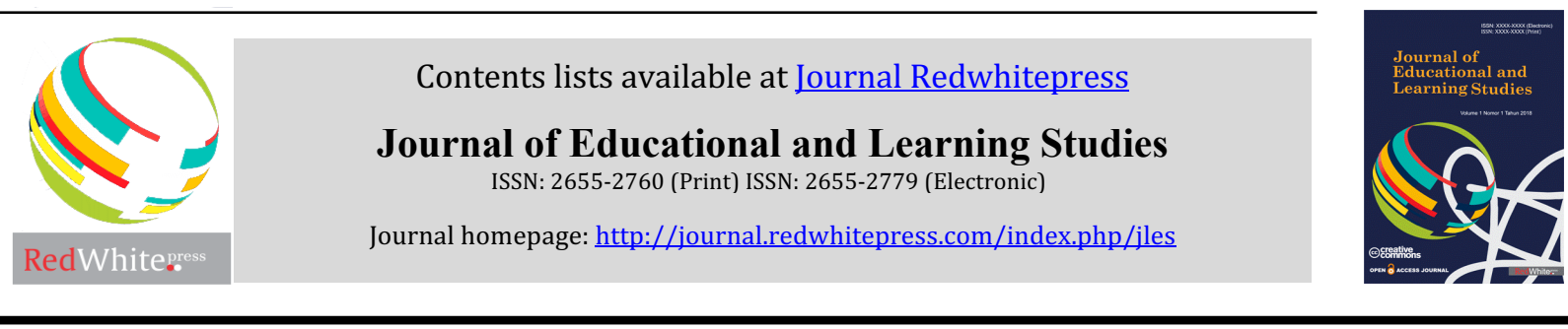

\title{
An Information Service by Using a Scientific Approach for Preventing Student Cyberbullying
}

\author{
Syarifuddin ${ }^{\left({ }^{*}\right)}$, A. Muri Yusuf ${ }^{2}$, Neviyarni $S^{3}$, Netrawati ${ }^{4}$ \\ ${ }^{1234}$ Guidance and Counseling Department, Universitas Negeri Padang, Padang, West Sumatera Indonesia
}

\begin{tabular}{|c|c|}
\hline Article Info & ABSTRACT \\
\hline Article history: & Cyber-bullying is a massive phenomenon happened to students. Student cyber- \\
\hline Received Des $27^{\text {th }}, 2019$ & $\begin{array}{l}\text { bullying must be prevented because it can give a negative physical and } \\
\text { psychological impact on the offender, audience and victim. One way that can }\end{array}$ \\
\hline Revised Mar $20^{\text {th }}, 2020$ & be done to prevent student cyber-bullying is to provide an information service \\
\hline Accepted Jun $26^{\text {th }}, 2020$ & $\begin{array}{l}\text { by using a scientific approach. The purpose of this research was to examine the } \\
\text { effectiveness of an information service by using a scientific approach to prevent }\end{array}$ \\
\hline Keyword: & $\begin{array}{l}\text { student cyber-bullying. The research method used was a quantitative research } \\
\text { with the true experiment design pretest-posttest group design. The research }\end{array}$ \\
\hline Cyberbullying & sample consisted of 30 students for the experimental group and 30 students for \\
\hline Information Service & the control group taken by using a proportional stratified random sampling \\
\hline Scientific approach & $\begin{array}{l}\text { technique. The data were analyzed by using the descriptive statistical analysis } \\
\text { and non-parameteric statistics using the Kolmogorov Smirnov } 2 \text { Independent } \\
\text { Sample analysis technique. The results of this research prove that the } \\
\text { information service by using a scientific approach is effective in preventing } \\
\text { student cyber-bullying. }\end{array}$ \\
\hline
\end{tabular}

\section{Corresponding Author:}

Syarifuddin

Universitas Negeri Padang

Email: sydarief22@gmail.com

\section{Introduction}

Students are ideally demanded to be active in achieving six educational focuses: spiritual strength, selfcontrol, personality, intelligence, noble character and skills needed for themselves, society, nation and country (Prayitno, 2018). However, the reality of some students still has a tendency to behave maladaptively that is behavior that deviates from social normality which will adversely affect the welfare of individuals and social groups. Deviant or maladaptive behavior of students is seen in schools including cyber-bullying. Cyberbullying is a form of bullying behavior carried out by electronic actors such as computers, mobile phones, internet, websites, chat rooms, e-mail and so on. Usually intended to terrorize victims by using writing, animation, images and recorded videos or films that are intimidating, hurting or cornering (Chadwick, 2014; Coloroso, 2007).

Based on data from the Komisi Perlindungan Anak Indonesia (KPAI) in 2011-2018, no children committed cyber-bullying from 2011 to 2015 while in 2016-2018 there was an increase in the number of cyber-bullying perpetrators, namely 34 perpetrators in 2016, 55 perpetrators in 2017 and 83 perpetrators in in 2018 there were 83 perpetrators. KPAI also displays data on the number of cyber-bullying victims from 2011-2018, there were no children who became the victims of cyber-bullying in 2011-2015 while in 2016-2018 there was an increase every year, there were 56 victims in 2016, 73 victims in 2017 and continued to increase to 97 victims 2018 (www.kpai.go.id). Based on data from the Asosiasi Penyelenggara Jasa Internet Indonesia (APJII) in 2019, there are around 49 percent of internet users who have been targeted by cyber-bullying. From the 49 percent, there 
were 31.6 percent often allowing such treatment and not doing anything. Meanwhile, there were 7.9 percent who responded to this treatment with similar cyber-bullying actions (apjii.or.id). In addition, the results of research conducted on 157 male students and 196 female junior high school students in Padang showed that $78 \%$ of respondents had seen cyber-bullying, $21 \%$ of respondents had been perpetrators and $49 \%$ of respondents had been victims. Cyber-bullying is mostly done through writing, sound or image media. The most widely used online media are facebook, short message and instagram (Afriyeni, 2017).

Cyber-bullying must be prevented because it can give a negative effect on the victim both physically and psychologically. Physically cyber-bullying can cause physical bullying such as fighting, psychologically the victim becomes insecure, likes to be alone, anxious, emotional, stressed and the effect is felt in long time and results in suicide (Arseneault, Bowes, \& Shakoor, 2010; Hinduja \& Patchin, 2010; Wolke, Copeland, Angold, \& Costello, 2013). In addition, cyber-bullying can also create an unsafe and uncomfortable academic environment so that it can further lead to violence, antisocial behavior, and other negative behaviors (Siregar, Yusuf \& Wahyuni, 2019).

Among the efforts that Guidance and Counseling teacher/Counselor can do to prevent cyber-bullying is to provide a basic service in the form of the classical information service carried out by using a scientific approach. The information service provided by using a scientific approach is the information service Guidance and Counseling provided classically designed so that students actively acquire knowledge, skills and attitudes through the steps of observing, formulating questions, gathering information, processing information and communicating and creating a products in the form of objects (objects), forms of presentation or writing (Daryanto, 2014; Direktorat Pembinaan SMP, 2016).

The information service provided by using the scientific approach is thought to be more effective than the information service provided by using the conventional approach. The results of the research proved that in traditional learning, information retention from teachers was 10 percent after 15 minutes and acquisition of contextual understanding was 25 percent. In learning based on a scientific approach, the information retention from teachers was more than 90 percent after two days and acquisition of contextual understanding was 50-70 percent (Daryanto, 2014). The scientific approach is the main approach mandated in the 2013 curriculum, and this approach is thought to be effective because it provides opportunities for students to explore and elaborate and actualize the material being studied (Rusman, 2015), encourage and inspire students to think critically, analytically and appropriate in identifying, understanding, solving problems and applying learning material (Sinambela, 2017) and can train students in communicating ideas, shaping students' abilities in solving problems systematically (Daryanto, 2014). Thus, the provision of the information service by using a scientific approach is expected to be able to enrich the cognitive domain of students about material related to efforts to prevent student cyber-bullying so that students have an attitude to avoid cyber-bullying in daily life.

This research aims to identify differences in student cyber-bullying who are provided with information services using a scientific approach with student cyber-bullying who were provided with the information service by using the conventional approach so that they will conclude which approach is more effective between the two approaches for use in information services in an effort to prevent student cyber-bullying. The research method used was a quantitative research with the experimental design of the non-equivalent control group design. The data were analyzed by using the descriptive statistical analysis and non-parameteric statistics.

\section{Method}

The research method used was a quantitative research with true experiments design pretest-posttest group design. The design was chosen because this research used samples with the same characteristics taken randomly from a homogeneous population (Sugiyono, 2015; Suryabrata, 2011). The population of this research was the students of grade VII and grade VIII of SMPN 17 Padang. The students of grade IX were not chosen as the research population because they focused on taking the National Examination, so they were not allowed to be researched by the school. The research sample needed in this research was 30 students for the experimental group and 30 students for the control group taken by using a proportional stratified random sampling technique. The decision to take the sample consisting of 30 students is by considering the average number of the students in each research group because this research was an experimental research that provided treatment which was an information servicein classical. This research instrument used the grand theory of cyber-bullying from (Coloroso, 2007) with the indicators which were intimidating, hurting or cornering others through electronic means by using writing, animation, pictures and videos. The questionnaire used a Likert scale with the alternative answers: very appropriate, appropriate, less appropriate, not appropriate and very inappropriate. The validity of the instrument was analyzed by using the Product Moment analysis, so from the 10 statement items there were 7 items that were valid and 3 items were invalid. The instrument reliability was determined by comparing the Cronbach's Alpha value which was 0.826 with 
Cronbach's Alpha minimum value which was 0.70. It was known that the Cronbach's Alpha instrument value was greater than the Cronbach's Alpha instrument minimum value $(0.826>0.70)$. Thus, it was concluded that this research instrument was reliable with a very reliable level of reliability (Hair, Black, Babin, Anderson, \& Tatham, 2010). The data were analyzed by using the descriptive statistical analysis and non-parameteric statistics using the Kolmogorov Smirnov 2 Independent Sample analysis technique. This method was used because it can compare two free samples or compare the data from different sources namely the data from the experimental group and the control group (Yusuf, 2014) for testing the effectiveness of the information service by using a scientific approach to prevent student cyber-bullying.

\section{Results and Discussions}

The information service provided by using the scientific approach was thought to be more effective than the information service provided by using the conventional approach. To prove the hypothesis in detail, please find the following analysis.

Table 1. The Results of the kolmogorovsmirnov 2 independent samples in the Posttest Student Cyber-bullying of the Experiment Group and the Control Group Test Statistics ${ }^{a}$

\begin{tabular}{llr}
\hline & & Score \\
\hline Most Extreme Differences & Absolute &, 467 \\
& Positive & 0,000 \\
& Negative &, 467 \\
Kolmogorov-Smirnov Z & & 1,807 \\
Asymp. Sig. (2-tailed) & &, 003 \\
\hline
\end{tabular}

Based on table 1 above, Asymp value. Sig. (2-tailed) obtained by 0.003 smaller than the significance value of $0.05(0.003<0.05)$. Then, $\mathrm{H}_{0}$ was rejected and $\mathrm{H}_{1}$ was accepted. It means that there are significant differences in the level of Student cyber-bullying between the experimental group that was provided the information service by using a scientific approach and the control group that was provided the by information services using the conventional approach. Thus, it can be concluded that information service by using a scientific approach is more effective in preventing student cyber-bullying than the information service provided by using the conventional approache. To see how the change in the student cyber-bullying scores in 30 experimental group students is showed clearly in the figure below.

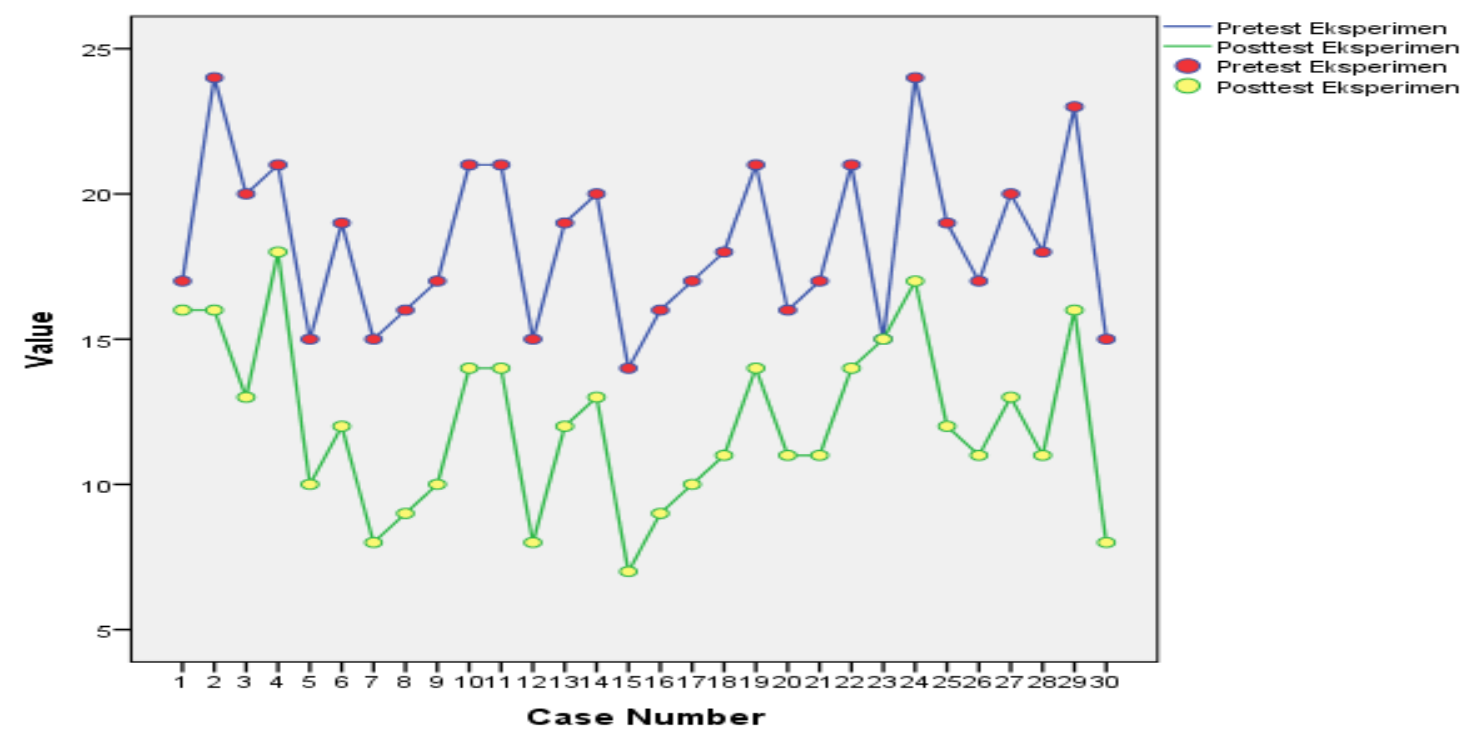

Figure 1. The Student Cyber-bullying Differences Before and After being given the Information Service by Using a Scientific Approach

Based on figure 1 above, it was illustrated that there was a decrease in the scores of student cyberbullying before and after being provided with the information service by using a scientific approach. This showed that the information service provided by using a scientific approach can prevent student cyberbullying. This conclusion does not mean that the conclusion that information services provided using 
conventional approaches cannot prevent student cyber-bullying. The information service provided by using a conventional approach can also prevent student cyber-bullying that is illustrated in the figure below.

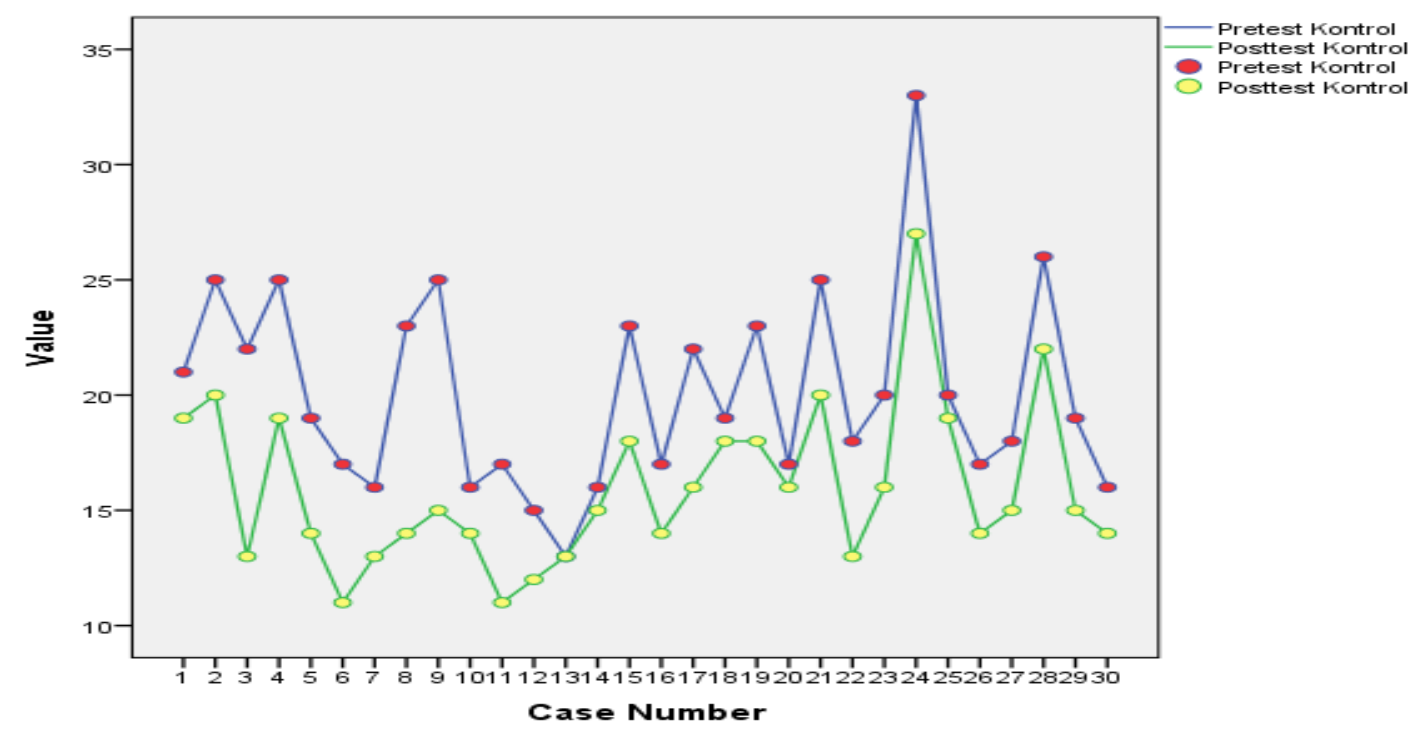

Figure 2. The Student Cyber-bullying Differences Before and After the Information Service given by Using the Conventional Approach

Based on figure 2 above illustrated a decrease in the scores of student cyber-bullying before and after being given the information service by using the conventional approach. It can be concluded that the information service provided by using the conventional approach can also prevent student cyber-bullying. However, after testing the hypothesis between the information service provided by using a scientific approach and the information service provided by using the conventional approach as shown in table 1, it can be concluded that the information service provided by using a scientific approach is more effective than by using the conventional approach in preventing student cyber-bullying.

The results of the hypothesis test above prove the theory that a scientific approach is more effective than the conventional approach (Direktorat Pembinaan SMP, 2016). There are several reasons why the information service provided by using a scientific approach have proven to be more effective in preventing student cyberbullying than the information service by using the conventional approach. First, the information service by using a scientific approach provides opportunities for students to explore and elaborate on the material being studied Rusman, 2015). The information service by using a scientific approach in practice requires students to understand the material in depth and repetitively at every step of understanding, asking, seeking information, associating, communicating and creating (Daryanto, 2014; Direktorat Pembinaan SMP, 2016). This profound and repetitive process can enrich the students' cognition about the information service material, especially the material about the efforts to prevent student cyber-bullying so that students have an attitude to avoid student cyber-bullying in daily life, both as perpetrators, spectators and victims. Second, a scientific approach in practice is a learning approach that is centered on students while the conventional approach is a learning approach that is centered on educators. The scientific approach requires students to be more active than Guidance and Counseling teacher/Counselor who only function as regulators of the information service process. Unlike the conventional approach in practice the Guidance and Counseling teacher/Counselor are more dominant so that sometimes this approach makes students feel bored and not interested in following the information service process (Ahmed, 2013; Dole, Bloom, \& Kowalske, 2016). Third, according to Regulation of the Minister of Education and Culture of the Republic of Indonesia Number 81 A of 2013 about Curriculum Implications of the General Guidelines for Learning, in each scientific step also requires some characters and competencies that must be possessed by students such as honesty, politeness, obedience to rules, tolerance, respecting people's opinions others, the ability to communicate well and develop a culture of good language. Demands in the process of the information service by using a scientific approach will train students to have good character in everyday life which in turn also has an effect on the efforts to prevent student cyber-bullying.

Based on the results of this research it is suggested for Guidance and Counseling teacher/Counselor to use a scientific approach rather than using the conventional approach in providing the information service to prevent student cyber-bullying. Because this research is an experimental research which is tested in a limited 
group, this research cannot be generalized in a wider group of students. Therefore, it is suggested to other researchers to be able to conduct further research such as a research and development to develop the information service modules or models by using a scientific approach to prevent student cyber-bullying so that they can be used against a broader group of students.

\section{Conclusions}

Based on the results of this research it was concluded that the information servicey using a scientific approach was effective in preventing student cyber-bullying. The results showed that there was a decrease in student cyber-bullying after given the information service by using a scientific approach. This is because the information service by using a scientific approach provides opportunities for students to explore and elaborate on material that is studied in depth and repeatedly at each step of observing, formulating questions, gathering information, processing information, communicating and creating. This profound and repetitive process can enrich the students' cognition about the information service material, especially the material about the efforts to prevent student cyber-bullying so that the students have an attitude to avoid student cyber-bullying in daily life, both as perpetrators, spectators and victims. In addition, a scientific approach is a learning approach that is centered on students who require students to be more active than Guidance and Counseling teacher/Counselor who only function as regulators of the information service process. The effectiveness of the information service by using a scientific approach is also caused because in each step the scientific approach requires several characters and competencies that must be possessed by students such as honesty, polite, obedient rules, tolerance, respecting the opinions of others, the ability to communicate well and develop good language-speaking culture. The demands in the process of the information service by using a scientific approach will train students to have good character in everyday life which in turn also has an effect on efforts to prevent student cyber-bullying.

\section{References}

Afriyeni, N. (2017). Perundungan maya (cyber-bullying) pada remaja awal. Jurnal Psikologi Insight, 1(1), 25-39.

Ahmed, A. K. (2013). Teacher-centered versus learner-centered teaching style. Journal of Global Business Management, 9(1), 22.

Arseneault, L., Bowes, L., \& Shakoor, S. (2010). Bullying victimization in youths and mental health problems:'Much ado about nothing'? Psychological Medicine, 40(5), 717-729.

Chadwick, S. (2014). Cyber-bullying. In Impacts of Cyber-bullying, Building Social and Emotional Resilience in Schools (pp. 11-29). Springer.

Coloroso, B. (2007). Penindas, tertindas, dan penonton. Resep memutus rantai kekerasan anak dari prasekolah hingga $S M U$. Jakarta: Serambi.

Daryanto. (2014). Pendekatan pembelajaran saintifik kurikulum 2013. Yogyakarta: Gava Media.

Direktorat Pembinaan SMP. (2016). Panduan pembelajaran untuk sekolah menengah pertama. Jakarta: DITPSMP KEMDIKBUD.

Dole, S., Bloom, L., \& Kowalske, K. (2016). Transforming pedagogy: Changing perspectives from teachercentered to learner-centered. Interdisciplinary Journal of Problem-Based Learning, 10(1), 1.

Hair, J. F., Black, W. C., Babin, B. J., Anderson, R. E., \& Tatham, R. L. (2010). Multivariate data analysis (7th ed.). New Jersey: Pearson Education Inc.

Hinduja, S., \& Patchin, J. W. (2010). Bullying, cyber-bullying, and suicide. Archives of Suicide Research, 14(3), 206-221.

Prayitno. (2018). Pola dasar keilmuan dan keprofesionalan pendidikan. Padang: UNP.

Rusman. (2015). Pemebelajaran tematik terpadu. Jakarta: PT. Raja Grafindo Persada.

Sinambela, P. (2017). Kurikulum 2013 dan implementasinya dalam pembelajaran. Generasi Kampus, 6(2).

Siregar, A. R., Yusuf, E. A., \& Wahyuni, P. (2019). Bullying at School and Impact of Empathy Training. The Journal of Social Sciences Research, 5(1), 117-120.

Sugiyono. (2015). Metode penelitian kombinasi (mix methods) (Alfabeta). Bandung.

Suryabrata, S. (2011). Metode penelitian. Jakarta: Raja Gravindo Persada. 
Wolke, D., Copeland, W. E., Angold, A., \& Costello, E. J. (2013). Impact of bullying in childhood on adult health, wealth, crime, and social outcomes. Psychological Science, 24(10), 1958-1970.

Yusuf, A. M. (2014). Metodologi penelitian kuantitatif, kualitatif \& penelitan gabungan. Jakarta: Prenadamedia Group. 